\title{
US unveils \$366 million computing boost
}

[ANAHEIM, CALIFORNIA] The Clinton administration is proposing a $\$ 366$ million increase in government investment in information technology and its applications to research. The plan is part of the budget for the fiscal year 2000, due to be presented to Congress next month.

Vice-President Al Gore announced the multi-agency package, a 28 per cent increase in real terms for such work, at last week's annual meeting of the American Association for the Advancement of Science, held in Anaheim, California.

The initiative is intended to build on previous and current programmes in computing and communications, bringing the total federal investment in information technology research and development to $\$ 1.8$ billion. President Bill Clinton is likely to give the proposal high priority within his overall budget plans (see Nature 395, 825; 1998).

The initiative, known as IT $^{2}$ (Information Technology for the Twenty-First Century), will incorporate long-term information technology research, advanced computing for science and engineering, and research on the economic and social implications of the information revolution (see box). About 60 per cent of the money will go to universitybased research.

$\mathrm{IT}^{2}$ is a response to the concerns and recommendations of the President's Information Technology Advisory Committee (PITAC). This panel, which is made up of representatives from industry and academia, concluded in August last year that the government was under-investing in long-term IT research, and suggested a doubling of current investment.

In his speech, Gore said that it was "awesome to contemplate" the science that would be made possible by research into the advanced applications of information technology. The possibilities in terms of jobs and economic prosperity were "even more awesome," he said.

"Our investments 30 years ago helped create the 7.4 million [jobs] we see in IT today. This initiative will help us sustain that prosperity, and holds out the promise of creating millions of new jobs for generations to come," Gore said. To accelerate this process, he added, the administration will also propose an extension to the $\$ 2.4$ billion research and experimentation tax credit.

Neil Lane, the president's science adviser, worked with federal agencies to develop a budget plan taking into account PITAC's recommendations. IT $^{2}$ is the result of six months of inter-agency planning under Lane and the National Science and Technology Council. "This is an extraordinary interagency team effort," says Lane.

IT $^{2}$ will involve the National Science

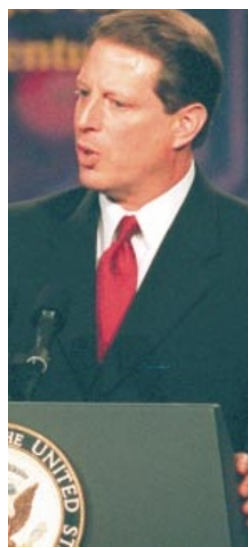

Foundation (NSF), the Department of Defense (including the Defense Advanced Research Projects Agency), the Department of Energy (DoE), the space agency NASA, the National Institutes of Health and the National Oceanic and Atmospheric Administration.

A senior management team, reporting directly to Lane, has 'Awesome promise': been formed to estabGore gives the news. lish policy and to coordinate the work of the initiative. It will initially consist of senior officials from each of the agencies involved in $\mathrm{IT}^{2}$, the Office of Management and Budget and the National Economic Council. This team will be supported by a working group chaired by the Assistant Director of the National Science Foundation, which will oversee the initiative's research programme.

One of the tasks of this new organization will be to develop and operate what Ernest Moniz, the Secretary for Energy, describes as

"a 'terascale' computing environment for the entire scientific community" - referring to the new infrastructure to be made available by NSF and DoE.

Rita Colwell of the NSF points out that $\mathrm{IT}^{2}$ cuts across science boundaries. "It will empower disciplines with the capacity to do the kind of computational analysis not possible before," she says.

The new money includes an extra $\$ 10$ million to support research into the social implications of technology. "In the whirlwind of the bio-revolution, we must hold tight to our oldest values," said Gore, who drafted legislation as a member of the House of Representatives to create a presidential bioethics commission.

NatashaLoder

\begin{tabular}{|c|c|c|c|c|}
\hline \multicolumn{5}{|c|}{$\begin{array}{l}\text { Extra research spending in proposed fiscal } 2000 \text { budget } \\
\$ \text { million }\end{array}$} \\
\hline Agency & $\begin{array}{l}\text { Fundamental } \\
\text { information } \\
\text { technology } \\
\text { research: } \\
\text { supplemental }\end{array}$ & $\begin{array}{l}\text { Advanced } \\
\text { computing } \\
\text { for science, } \\
\text { engineering } \\
\text { and the nation }\end{array}$ & $\begin{array}{l}\text { Ethical, } \\
\text { legal and social } \\
\text { implications } \\
\text { and workforce } \\
\text { programmes }\end{array}$ & Total \\
\hline DoD & 100 & 0 & 0 & 100 \\
\hline DoE & 6 & 62 & 2 & 70 \\
\hline NASA & 18 & 19 & 1 & 38 \\
\hline $\mathrm{NHH}$ & 2 & 2 & 2 & 6 \\
\hline NOAA & 2 & 4 & 0 & 6 \\
\hline NSF & 100 & 36 & 10 & 146 \\
\hline Total & 228 & 123 & 15 & 366 \\
\hline
\end{tabular}

\section{Warning on pitfalls in measuring research}

[LOS ANGELES] Federal agencies should not try to measure the output of the research they fund by using performance indicators that foster 'non-productive' efforts by researchers, a report from the US National Academy of Sciences is likely to warn.

The report, by the academy's Committee on Science, Engineering and Public Policy (COSEPUP), is also expected to point out that, although the training of graduate students and postdocs is an important responsibility of research agencies, the development of human resources is not addressed in most of their plans.

The interim findings were described by COSEPUP member Mildred Dresselhaus, Institute Professor of Electrical Engineering and Physics at the Massachusetts Institute of Technology, at the American Association for the Advancement of Science (AAAS) meeting in Anaheim, California, last week.

The Government Performance and Results Act (GPRA), passed by Congress in 1993, requires all federal agencies to report on the results of their activities annually. But measuring research has proved particularly difficult, and ten agencies have come up with varying implementations.

The COSEPUP report, due to be published in full next month, is intended to identify the most effective ways of assessing the results of research. It will also look at how the federal government can better incorporate research activities into performance plans.

Dresselhaus said there was a strong inter-agency consensus that the practical outcomes of basic research per se could not be captured by purely quantitative measures. Although the report finds that peer review is the primary method for assessing the quality of research, said Dresselhaus, agencies apply this in very different ways.

The AAAS meeting was told that the US research community has generally low levels of awareness of, and involvement in, GPRA. Where there has been awareness, there is often resistance and concern over its potential to alter the research environment, for example by emphasizing the value of applied research with practical outcomes.

Nevertheless, Rosina Bierbaum, of the Office of Science and Technology Policy, told a separate session during the AAAS meeting that GPRA was not going to go away. "Science is going to be managed to some extent - with or without the help of scientists," she said. "I suggest it would be better with their help." 